\title{
Comparative cytogenetic analysis in Erythrolamprus snakes (Serpentes: Dipsadidae) from Argentina
}

\author{
CAMILA FALCIONE ${ }^{1}$, ALEJANDRA HERNANDO ${ }^{1}$ and MARÍA JOSÉ BRESSA ${ }^{2}$ \\ ${ }^{1}$ Laboratorio de Herpetología, Facultad de Ciencias Exactas y Naturales y Agrimensura, \\ Universidad Nacional del Nordeste, Avenida Libertad 5470, Codigo Postal 3400, Corrientes, Argentina \\ ${ }^{2}$ Instituto de Ecología, Genética y Evolución de Buenos Aires/IEGEBA - CONICET, Departamento de Ecología, Genética \\ y Evolución, Facultad de Ciencias Exactas y Naturales, Universidad de Buenos Aires, Ciudad Universitaria, Avenida \\ Intendente Güiraldes, 2160, $4^{\circ}$ piso, Pabellón II (C1428EHA), Ciudad Autónoma de Buenos Aires, Argentina
}

Manuscript received on May 18, 2017; accepted for publication on October 9, 2017

\begin{abstract}
We described the karyotypes of five snake taxa from Argentina: Erythrolamprus almadensis, E. ceii, E. poecilogyrus caesius, E. p. schotti and E. p. sublineatus, and also intergrading individuals between the last two subspecies by conventional staining, chromosome bandings and fluorescent in situ hybridization (FISH) with $28 \mathrm{~S}$ ribosomal DNA probes. Erythrolamprus ceii and E. almadensis share a diploid chromosome number of $2 \mathrm{n}=28$, whereas in E. poecilogyrus intraspecific variations were observed: $E$. $p$. caesius has $2 \mathrm{n}=28, E$. $p$. schotti and E. p. sublineatus as well as in the intergrading individuals have $2 \mathrm{n}=$ 32. In E. almadensis and E. p. caesius, the $2^{\text {nd }}$ and $6^{\text {th }}$ chromosome pairs respectively are heteromorphic by size, morphology and C-banding pattern. These results allow us to suggest that these chromosome pairs might be considered as the ZW sex chromosomes in these species. The present comparative cytogenetic analyzes contributes to the already remarkable karyotypic variability in Erythrolamprus genus and propose a hypothesis about potential mechanisms involved in the chromosome evolution among taxa analyzed. Furthermore, the karyotypic differences observed between E. p. caesius $(2 \mathrm{n}=28)$ and E. p. schotti and $E$. p. sublineatus $(2 \mathrm{n}=32)$ might play a causal role in speciation.
\end{abstract}

Key words: Ag-NOR, C-banding, Xenodontini, fluorescent banding, rDNA-FISH, sex chromosomes.

\section{INTRODUCTION}

The cytogenetic analysis has been useful for taxonomic studies in Serpentes with inter- and intraspecific chromosome variability as Micrurus (Gutiérrez and Bolaños 1981) and Vipera (Aprea et al. 2006). Moreover, the differences in the karyotype through the redistribution of the chromosomes

Correspondence to: Camila Falcione

E-mail: camilafalcione@hotmail.com have been identified as a key mechanism in the evolutionary process of speciation (White 1968, 1969, Olmo 2005).

The Xenodontini comprises roughly 70 species of South American Dipsadidae snakes, currently grouped in three genera: Erythrolamprus Boie 1826, Lygophis Fitzinger 1843 and Xenodon Boie 1826 (Vidal et al. 2010, Grazziotin et al. 2012, Pyron et al. 2013, Uetz and Hošek 2013). Erythrolamprus includes 48 species distributed in Central and South 
America (Vidal et al. 2000, Zaher et al. 2009, see debate in Curcio et al. 2009, Uetz and Hošek 2013). Cytogenetic studies were carried out in only six species of Erythrolamprus by conventional staining and the number and location of nucleolar organizer regions (NORs) were determined in E. poecilogyrus schotti by fluorescent in situ hybridization (FISH) (Beçak et al. 1966, 1971, 1975, Beçak and Beçak 1969, Gutiérrez et al. 1984, Trajtengertz et al. 1995). Despite the scarce cytogenetic information available, karyotype variability has been reported among the species studied, i.e., karyotypes with 28 chromosomes that differ in number of macroand micro-chromosomes and in morphology of macro-chromosomes, and one karyotype with 32 chromosomes (Beçak et al. 1966, 1971, 1975, Beçak and Beçak 1969, Gutiérrez et al. 1984). On the other hand, in E. almadensis, E. miliaris, E. aesculapii venustissimun and E. bizona the $4^{\text {th }}$ chromosome pair was recognized as ZW sex pair (Beçak et al. 1966, 1975, Beçak and Beçak 1969, Gutierrez et al. 1984).

In this cytogenetic study, we describe the karyotype of Argentinean snakes included in poecilogyrus morphological group (Cei 1993): Erythrolamprus almadensis (Wagler 1824), E. ceii (Dixon 1991), E. poecilogyrus caesius (Cope 1862), E. p. schotti (Schlegel 1837) and E. p. sublineatus (Cope 1860) and the intergrading individuals between the last two subspecies through conventional staining, different chromosome banding (C, DAPI/ $\mathrm{CMA}_{3}$ and AgNOR) and fluorescent in situ hybridization (FISH) of ribosomal DNA. Erythrolamprus poecilogyrus (Wied-Neuwied 1825) is considered one of the most noteworthy examples of polymorphism due to the geographic variation in color and design patterns and natural mosaic of morphometric characters and lepidosis (Dixon and Markezich 1992). The cytogenetic characters described for each analyzed taxon were taxonomically informative and allowed us to provide a hypothesis about potential mechanisms involved in the chromosome evolution into the poecilogyrus group.

\section{MATERIALS AND METHODS}

Cytogenetic analyses were performed on females and males of Erythrolamprus ceii, E. almadensis, E. poecilogyrus caesius, E. p. schotti and E. p. sublineatus and intergrading individuals (see details in Appendix). Voucher specimens are deposited in the Herpetological Collection of the National University of the Northeast (UNNEC), Corrientes, República Argentina.

Erythrolamprus poecilogyrus subspecies were identified by the different color patterns according to Fernandes da Silva (2006). Individuals with intermediate patterns of coloration between $E$. $p$. schotti and E. p. sublineatus were considered as intergrading individuals.

The specimens were injected intraperitoneally with $0.1 \%$ colchicine $(1 \mathrm{ml} / 100 \mathrm{~g}$ body weight) for 3 hours prior to animal dissection. We practiced euthanasia according to the method described by Beaupre et al. (2004). The intestine was dissected and swollen for 50 minutes at RT in a hypotonic solution $(0.075 \mathrm{M} \mathrm{KCl})$, cut into small fragments, and then fixed in freshly prepared fixative solution (methanol:glacial acetic acid, 3: 1) and stored at $-20^{\circ} \mathrm{C}$ until further use.

For mitotic chromosome preparations, twothree intestine fragments were transferred to a tube with a few drops of $60 \%$ acetic acid for a few minutes until the epithelial cells shed, and then the gut fragments were removed. Some drops of cell suspension were carefully placed onto slides, which had been previously pre-heated in a thermal bath at $45^{\circ} \mathrm{C}$ for maintaining a thin film of water at the time when the drops fall on the slide. Cells were spread on the slide using a heating plate at $45^{\circ} \mathrm{C}$ as described in Traut (1976). Then, the preparations were dehydrated in an ethanol series $(70,80$, and $96 \%, 30 \mathrm{~s}$ each) and stored at $-20^{\circ} \mathrm{C}$ until further 
use. For conventional staining, preparations were stained with $10 \%$ Giemsa solution $(\mathrm{pH}$ 6.8) for 7 min at RT.

$\mathrm{C}$-and sequential fluorescent bandings were performed according to Papeschi (1988) and Poggio et al. (2011). Detection of the nucleolus organizer regions (NORs) on mitotic chromosomes was done following the silver staining method of Howell and Black (1980). Fluorescent in situ hybridization (FISH) with biotinylated 28S rDNA probe of Xenopus laevis was performed following the procedure in Bressa et al. (2009). The 28S rDNA fragment was labeled by nick translation with biotin 14-dUTP (Bionick Labeling System, GIBCO BRL, USA) (Bressa et al. 2009). Hybridization signals were detected with $\mathrm{Cy} 3$-conjugated streptavidin (Jackson ImmunoRes. Labs. Inc., West Grove, PA, USA).

Chromosome preparations were observed in a epifluorescence microscope Leica DMLB equipped with a Leica DFC350 FX CCD camera and Leica IM50 software, version 4.0 (Leica Microsystems Imaging Solutions). Black-and-white images of chromosomes were recorded separately for each fluorescent dye. Images were pseudocolored (light blue for DAPI, green for $\mathrm{CMA}_{3}$, and red for Cy3) and processed with an appropriate software.

Chromosome sizes were measured using the computer application MicroMeasure version 3.3 (available at http://www.colostate.edu/Depts/ Biology/Micromeasure) (Reeves and Tear 2000). Measurements were performed on ten metaphase plates of each specimen. Relative chromosomal lengths (RL) and centromeric index (CI) were calculated and expressed as percentage of the haploid set. These data were used to describe the karyotype of each Argentinean snake according to Levan et al. (1964). The chromosomal formula was determined following to Peccinini-Seale (1981) $(2 \mathrm{n}=\mathrm{I}+\mathrm{II}+\mathrm{III})$ being $\mathrm{I}=$ metacentric or submetacentric macrochromosomes, II = telocentric or subtelocentric macrochromosomes and III $=$ microchromosomes. Based on RL values three chromosome groups could be recognized: small (1 $-2.5 \%$ of haploid set), medium (2.51 - 5\%) and large $(>5 \%)$.

\section{RESULTS}

\section{CHROMOSOME COMPLEMENTS}

Erythrolamprus ceii, E. almadensis and E. poecilogyrus caesius share a diploid chromosome number $2 \mathrm{n}=28$ (Fig. 1a-d). Based on the RL values the chromosome pairs 1 to 3 are larger, 4 to 7 pairs have medium size and 8 to 14 pairs are smaller (Fig. 1a-d; Table I).

The karyotype formula is $28=28+0+0, \mathrm{NF}=$ 56 in E. ceii and E. almadensis (Fig. 1a-c; Table I). In females of $E$. almadensis, the chromosome pair 2 is heteromorphic in size, being one homologous chromosome smaller $(\mathrm{RL}=6.77 \%)$ than the other $(\mathrm{RL}=8.66 \%)$, whereas in males both homologous have the same relative size $(\mathrm{RL}=7.35 \%)$ (Table I). In males of E. poecilogyrus caesius, the karyotype formula is $28=26+2+0, \mathrm{NF}=54$ with a pair 6 formed by two subtelocentric chromosomes, whereas females have $28=27+1+0$, in which the pair 6 comprises one metacentric chromosome and the other subtelocentric (Fig. 1d; Table I).

The karyotype formula of both sexes of E. poecilogyrus schotti, E. p. sublineatus and intergrading individuals is $32=24+8+0, \mathrm{NF}=56$ (Fig. 1e-g). The chromosome pairs 1, 4-6, and $9-16$ are metacentric and the pairs 2, 3, 7, and 8 are telocentric (Fig. 1; Table I). According to the RL values, the pair 1 belongs to the large group, the pairs 2 to 9 to the medium one, and pairs 10 to 16 to the smaller (Table I). In these taxa neither a heteromorphic pair and no secondary constriction is observed on the poecilogyrus group chromosome complements. 

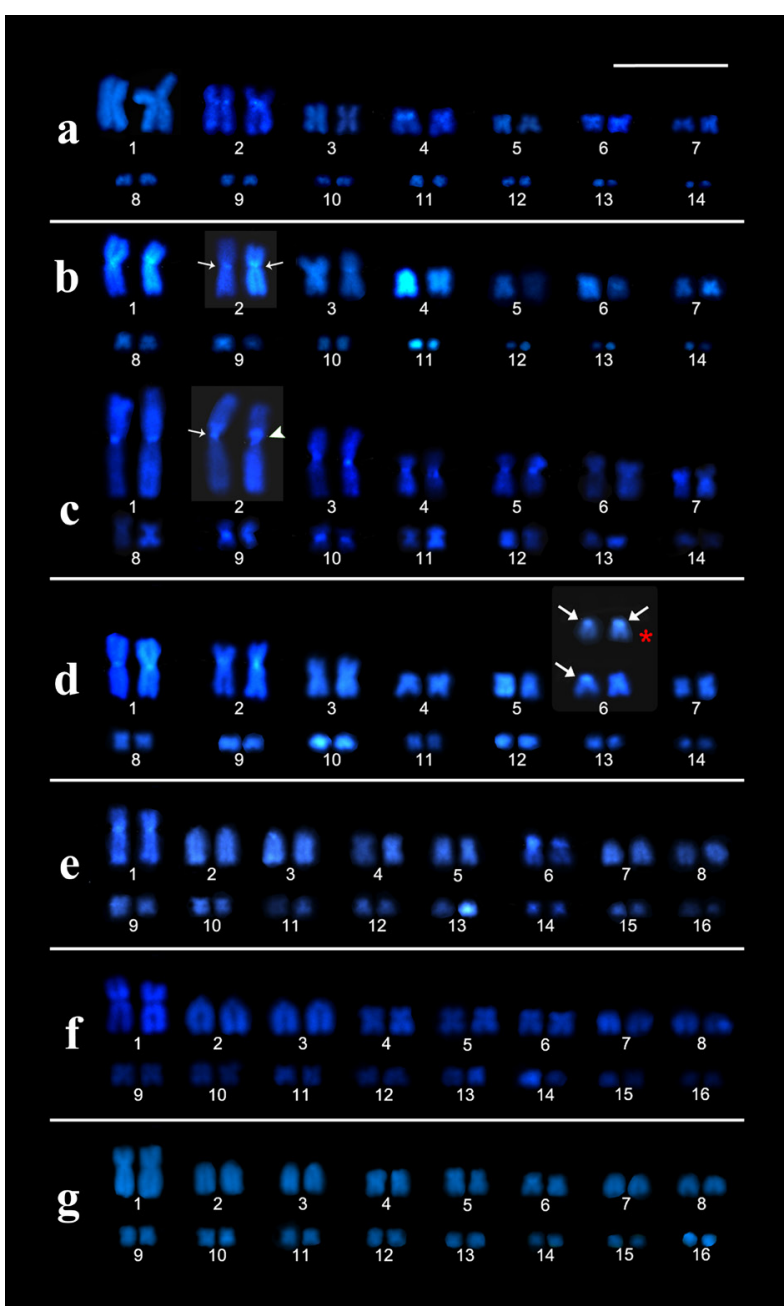

Figure 1 - C-banding patterns staining with DAPI on mitotic chromosomes of Erythrolamprus poecilogyrus group species. a) E. ceii, b) E. almadensis (male), c) E. almadensis (female), d) E. poecilogyrus caesius, e) E. p. schotti, f) E. p. sublineatus and g) Intergrading individuals. Arrowhead: pericentromeric C-positive band. Arrows: centromeric C-positive bands in the heteromorphic chromosome pairs of E. almadensis and E. poecilogyrus caesius. Red asterisk: pair 6 in males in E. poecilogyrus caesius. The gray boxes indicate the heteromorphic pairs. Scale bar $=10 \mu \mathrm{m}$.

\section{C-AND FLUORESCENT BANDINGS}

In Erythrolamprus ceii, three chromosome pairs have heterochromatic $\mathrm{C}$ - positive bands at centromeric regions, i.e., the chromosome pair 2, 4 and 6 (Fig. 1a). In males of E. almadensis, the chromosome pairs $1,2,3,6$, and 9 . In female mitotic preparations, C-positive bands are present at centromeric regions of the chromosome pairs
1, 3-6, 9, and 10 (Fig. 1b, c). In the heteromorphic chromosome pair 2, the large homologous chromosome shows a C-positive band at the centromeric region, whereas the small one has a pericentromeric C-positive band in the $\mathrm{p}$ arm (Fig. 1c). In E. p. caesius, C-positive centromeric bands are revealed on each chromosome of pairs 1 and 2 (Fig. 1d). Besides, both sexes show differences in the C-banding pattern of the chromosome pair 6. In males, each subtelocentric homologous chromosome has C-positive centromeric bands. In females, no C-bands are detected on the metacentric chromosome, whereas a C-positive band is observed in its subtelocentric homologous (Fig. 1d). In Erythrolamprus p. schotti, the chromosome pair 1, 6 and 14 show heterochromatic C-positive bands placed on centromeric regions (Fig. 1e). No C-positive bands were detected in both E. $p$. sublineatus and the intergrading specimens (Fig. 1f, g).

All mitotic chromosomes of E. ceii are stained homogenously without any DAPI- or $\mathrm{CMA}_{3}$-bright bands. A small chromosome pair of E. almadensis, shows a DAPI-negative/CMA -bright band at the centromeric region (Fig. 2a-c). In mitotic chromosomes of E. p. caesius, DAPI-dark/CMAbright bands are observed at centromeric regions of the chromosome pairs 3, 5, 10,11,12, 13, 14 and in one homologous chromosome of the pairs 1 and 6, DAPI-bright/CMA 3 -bright centromeric bands in chromosome pair 2, and DAPI-bright/CMA -dark bands at centromeric regions of pairs 7,8 and 9 (Fig. 2d-f). The fluorescent banding in E. p. schotti reveals DAPI-dark/CMA -bright bands placed on centromeric regions of two small chromosome pairs (Fig. 2g-i). No DAPI/CMA 3 bands are detected in mitotic chromosomes of E. p. sublineatus. Lastly different fluorescent banding patterns are observed in the intergrading individuals: i) all chromosomes are stained homogenously without any DAPI- or $\mathrm{CMA}_{3}$-bright bands, ii) centromeric DAPI-dark/ $\mathrm{CMA}_{3}$-bright bands on the chromosome pair 1 , a medium-sized and small pairs (Fig. 2j-1), iii) DAPIdark/CMA - -bright bands at telomeric regions on 


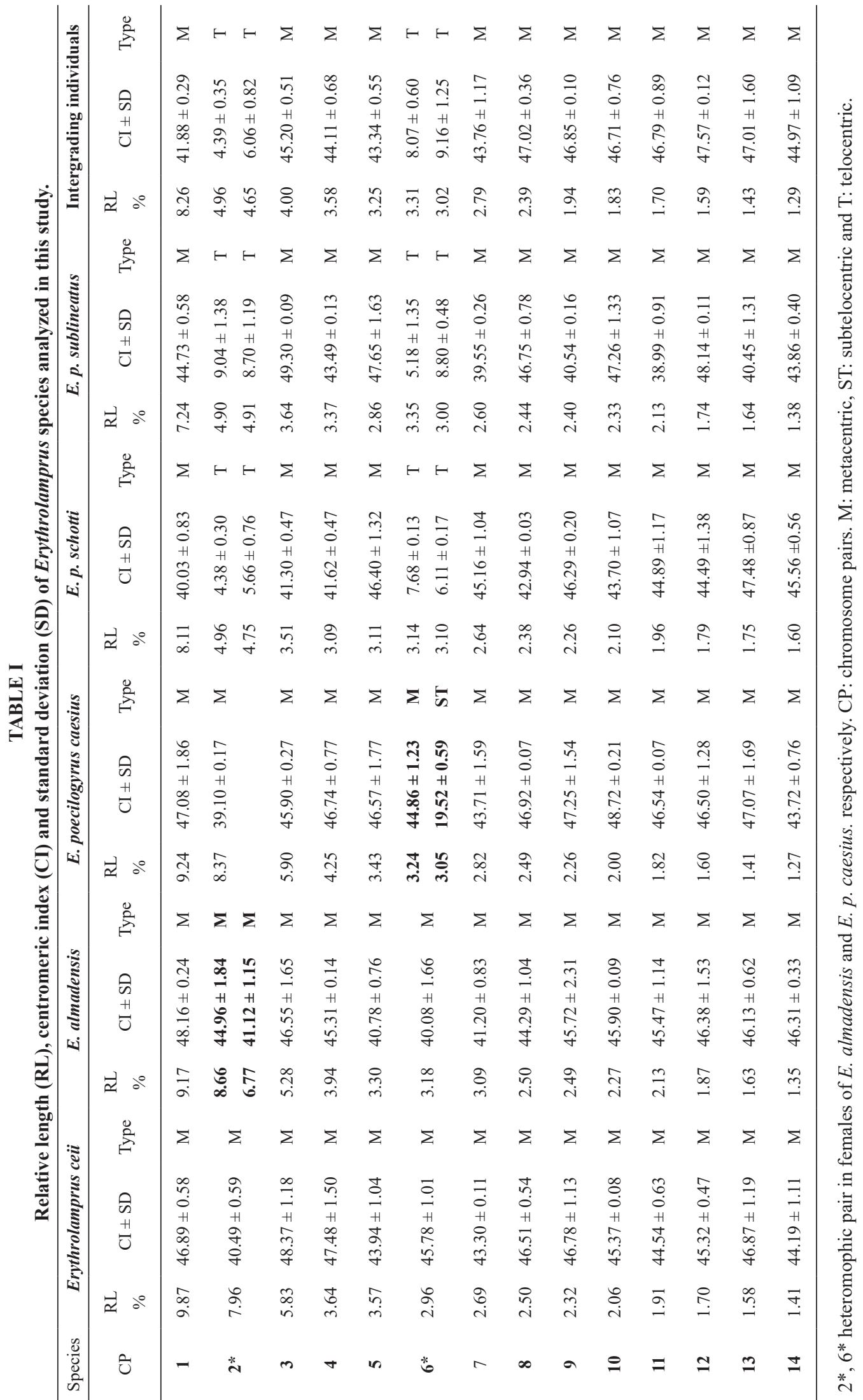



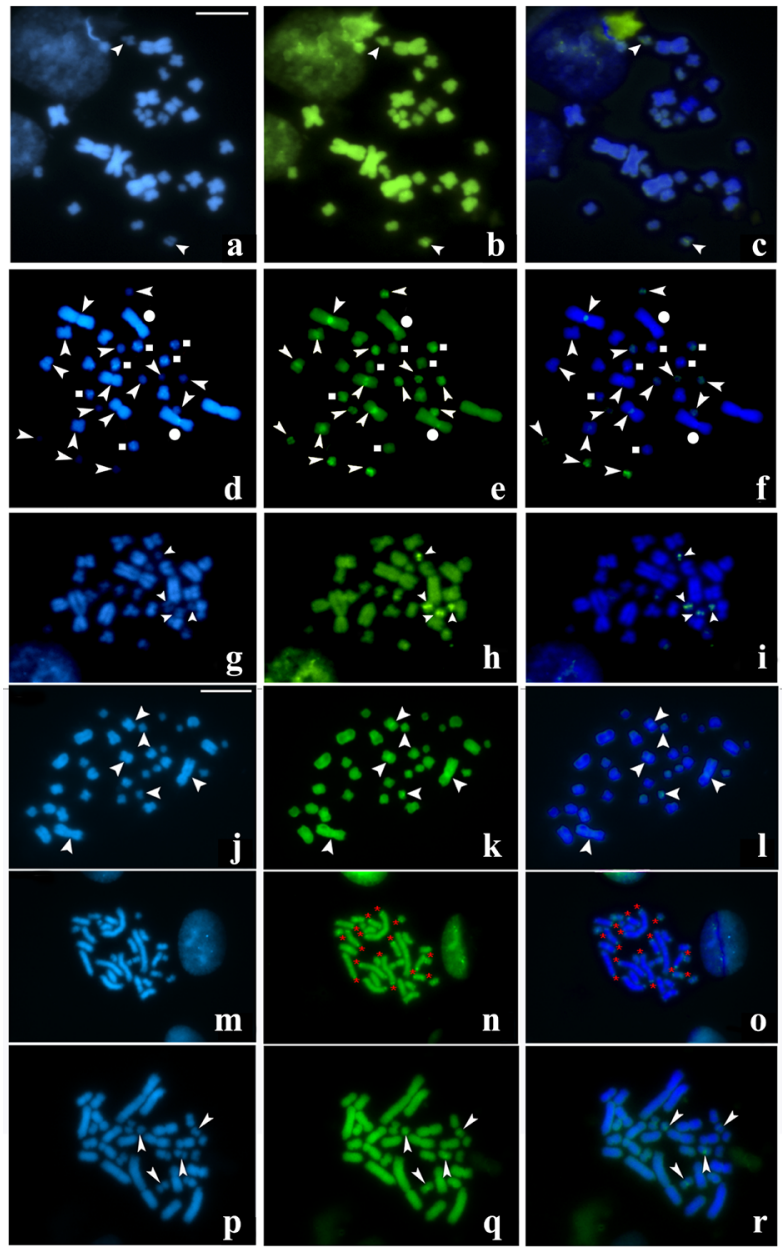

Figure 2 - Sequential DAPI/ $\mathrm{CMA}_{3}$ banding patterns of the Erythrolamprus poecilogyrus group species. a-c, E. almadensis. d-f, E. p. caesius. g-i, E. p. schotti. j-r, intergrading individuals. a, d, g, j, m, p DAPI banding; b, $\mathbf{e}, \mathbf{h}, \mathbf{k}, \mathbf{n}, \mathbf{q} \mathrm{CMA}_{3}$ banding and $\mathbf{c}, \mathbf{f}, \mathbf{i}, \mathbf{l}, \mathbf{o}, \mathbf{r}$ combination of figures $\mathbf{a}+\mathbf{b}, \mathbf{d}+\mathbf{e}, \mathbf{g}+\mathbf{h}, \mathbf{j}+\mathbf{k}, \mathbf{m}+\mathbf{n}$ and $\mathbf{p}+\mathbf{q}$ respectively. Arrowheads: centromeric DAPI-dark/CMA -bright bands. Dots: centromeric DAPI-bright/CMA -bright bands. Squares: centromeric DAPI-bright/CMA -dark bands. Red asterisks: telomeric DAPI-dark/CMA -bright bands. Scale bar $=10 \mu \mathrm{m}$.

most chromosome pairs (Fig. 2m-o), and iiii) centromeric DAPI-dark/CMA 3 -bright bands on two small chromosome pairs (Fig. 2p-r).

\section{LOCATION OF rDNA BY FISH AND Ag-NOR BANDING}

At mitotic metaphases, positive Ag-NORs are observed in one of the small chromosome pairs in all species of the Erythrolamprus analyzed, i.e. Erythrolamprus ceii (Fig. 3a), E. almadensis (Fig. 3b), E. p. caesius (Fig. 3c), E. p. schotti (Fig. 3d), and E. p. sublineatus (Fig. 3e), and also in intergrading individuals (Fig. 3f). In mitotic metaphases of males of E. p. sublineatus and females of E. p. schotti, FISH experiments with the 28S rDNA probe showed a single cluster of rDNA genes located in each homologous chromosomes of one of the small pair (Fig. 3g-1).

\section{DISCUSSION}

The present comparative study provides new evidences that strengthen the remarkable karyotype variability in Xenodontini tribe and also in Erythrolamprus genus (Falcione et al. 2016) (Table II). To the present, two diploid chromosome numbers are described for the genus: $2 \mathrm{n}=28$ in E. aesculapii venustissimun, E. epinephelus, E. bizona, E. miliaris and E. almadensis, but showing variations in the number of uni- and biarmed macro- and micro-chromosomes (Table II) (Beçak et al. 1966, 1975, Beçak and Beçak 1969, Gutierrez et al. 1984), and $2 \mathrm{n}=32$ in E. poecilogyrus and E. p. schotti (Beçak et al. 1971, Trajtengertz et al. 1995).

In relation to the number of biarmed and uniarmed macro-chromosomes (M) pairs, it deserves attention that all the species and subspecies of the genus Erythrolamprus with $2 \mathrm{n}=28$ exhibit a low number of uni-armed M pairs: two in E. aesculapii venustissimun (9 and 10) and E. epinephelus (6 and 9), one in E. bizona (pair 6), and without any of them in E. miliaris, E. ceii and E. almadensis (Table II). Particularly, into the poecilogyrus group inter- and intra-specifics chromosomes variations are revealed about to the number of uni- and biarmed: Erythrolamprus ceii and E. almadensis have karyotypes with $2 \mathrm{n}=28=28+0+0(\precsim /$ $)$ whereas in E. poecilogyrus intraspecifics variations were observed: E. p. sublineatus and E. p. schotti and the intergrading individuals have $2 \mathrm{n}=32=24+8+0$ 


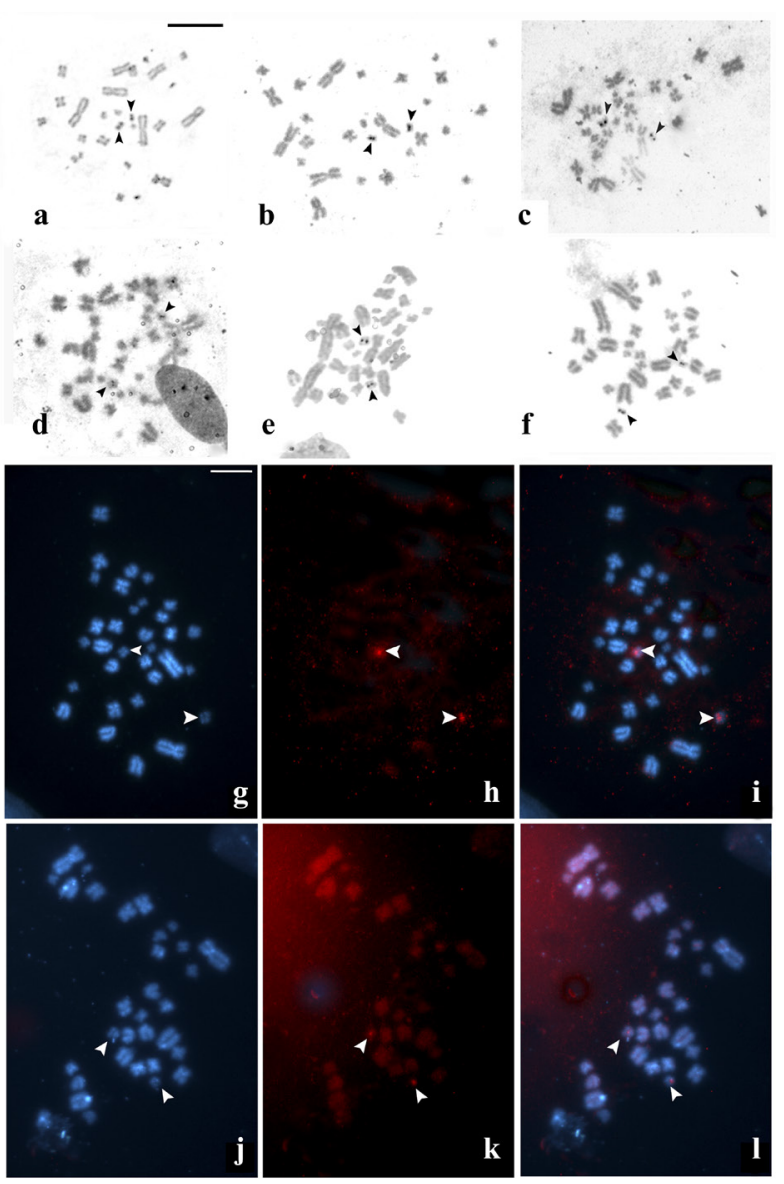

Figure 3 - Location of rDNA by FISH and Ag-NOR banding of Erythrolamprus poecilogyrus group species. Ag-NOR-stained metaphases of a) Erythrolamprus ceii, b) E. almadensis, c) E. p. caesius, d) E. p. schotti, e) E. p. sublineatus and f) Intergrading individuals. The black arrowheads indicate the chromosomes bearing NORs. FISH with DNAr 28S probe in male mitotic metaphase of E. p. sublineatus (g-i) and female of E. p. schotti (j-l). Chromosomes counterstained with DAPI (blue) (g, j), hybridization signals (red) (h, k) and combination of figures $\mathbf{g}, \mathbf{j}$ with $\mathbf{h}$ and $\mathbf{k}$, respectively (i-l). The white arrowheads indicate the hybridization signals and the chromosomes carriers. Scale bar $=10 \mu \mathrm{m}$.

$(\widehat{\jmath} / q)$ whereas $E$. p. caesius has $2 \mathrm{n}=28=26+2+0$ J/ $27+1+0$ o.

The comparison of cytogenetic characteristics within E. poecilogyrus allow distinguishing two karyotypes: one with both higher diploid chromosome number and fundamental number $(2 \mathrm{n}=32, \mathrm{NF}=56)$, consisting of less biarmed M and more uni-armed M $(24+8+0)$ (E. poecilogyrus schotti, E. p. sublineatus and intergrading individuals), and the other with both lower diploid number and fundamental number $(2 \mathrm{n}=28, \mathrm{NF}=$ $54)$, formed by more biarmed $M$ and less uni-armed $\mathrm{M}(26+2+0)$ (E. p. caesius).

In snakes, the karyotype $2 \mathrm{n}=36$ (16 macrochromosomes +20 micro-chromosomes) is proposed to be an ancestral character shared throughout most families (Oguiura et al. 2009). Taking into account this hypothesis, both chromosome changes must have occurred throughout the karyotype evolution of Erythrolamprus poecilogyrus group and the different karyotypes should be considered as derivatives. The lowest diploid numbers could derive through fusion between macro and microchromosomes and/or between micro-chromosomes. Moreover, differences in chromosome morphology could be due to pericentric inversions and heterochromatin addition. In Squamata, there is a trend to reduce the number of micro-chromosome because of translocation onto macro-chromosomes, or fusion among micro-chromosomes (Olmo 2008, Uno et al. 2012).

Concerning the content, distribution and location of constitutive heterochromatin, different C-banding patterns have been previously described in snakes, i.e., large blocks at centromeric regions, and also at terminal and interstitial position in macro-chromosomes, whole heterochromatic arms (Mengden and Stock 1980, Moreno et al. 1987), only placed on microchromosomes (Singh and Majumdar 1994) and scarce heterochromatin in autosomes (Mezzasalma et al. 2014). The results obtained here revealed a low content of constitutive heterochromatin among the species of the poecilogyrus group, intra- and intraspecific differences and the enrichment of heterochromatin mainly of CG base pairs.

The karyotypes of Erythrolamprus ceii, E. almadensis and E. p. caesius $(2 \mathrm{n}=28)$ are similar after conventional staining, although we detected differences from the comparison of their DAPI/ $\mathrm{CMA}_{3}$ banding patterns. Our cytogenetic 
TABLE II

Diploid number, chromosome formula and sex chromosome morphology and position into Erythrolamprus genus.

\begin{tabular}{|c|c|c|c|c|c|c|}
\hline \multirow[t]{2}{*}{ Species } & \multirow[t]{2}{*}{$2 n$} & \multirow{2}{*}{$\begin{array}{l}\text { Chromosome } \\
\text { formula }\end{array}$} & \multicolumn{2}{|c|}{ Sex chromosomemorphology } & \multirow[t]{2}{*}{ ZW position } & \multirow[t]{2}{*}{ References } \\
\hline & & & Z & $\mathrm{W}$ & & \\
\hline $\begin{array}{c}\text { Erythrolamprus } \\
\text { aesculapii } \\
\text { venustissimun }\end{array}$ & 28 & 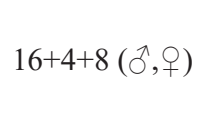 & Metacentric & Submetacentric & $4^{\text {th }}$ pair & $\begin{array}{c}\text { Beçak et al. 1966, Beçak and } \\
\text { Beçak } 1969\end{array}$ \\
\hline E. epinephelus & 28 & 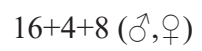 & & - & - & Gutiérrez et al. 1984 \\
\hline \multirow[t]{2}{*}{ E. miliaris } & 28 & $19+1+8($ () & Metacentric & Acrocentric & $4^{\text {th }}$ pair & \multirow{2}{*}{ Beçak and Beçak 1969} \\
\hline & & 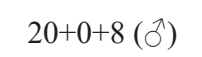 & & - & - & \\
\hline E. bizona & 28 & $18+2+8(q)$ & Submetacentric & Submetacentric & $4^{\text {th }}$ pair & Gutiérrez et al. 1984 \\
\hline \multirow[t]{3}{*}{ E. almadensis } & 28 & $27+1+0(+9)$ & Metacentric & Acrocentric & $4^{\text {th }}$ pair & \multirow{2}{*}{ Beçak et al. 1975} \\
\hline & & $28+0+0(ふ)$ & & - & - & \\
\hline & & 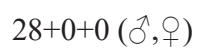 & Metacentric & Metacentric & $2^{\text {nd }}$ pair & This study \\
\hline E. ceii & 28 & $28+0+0(\hat{\partial},+$, $)$ & & - & - & This study \\
\hline \multirow[t]{2}{*}{$\begin{array}{l}\text { E. poecilogyrus } \\
\text { caesius }\end{array}$} & 28 & $27+1+0(+9)$ & Subtelocentric & Metacentric & $6^{\text {th }}$ pair & \multirow{2}{*}{ This study } \\
\hline & & $26+2+0($ ठ $)$ & & - & - & \\
\hline E. poecilogyrus & 32 & - & & - & - & Beçak et al. 1971 \\
\hline \multirow[t]{2}{*}{ E.p. schotti } & 32 & - & & - & - & Trajtengertz et al. 1995 \\
\hline & 32 & 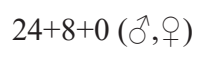 & & - & - & This study \\
\hline E.p. sublineatus & 32 & $24+8+0(\hat{\jmath},+9)$ & & - & - & This study \\
\hline
\end{tabular}

findings provide a deeper knowledge of chromatin organization and constitution of the chromosomes among related species. It should be mentioned that the fluorescence bands patterns of the intergroup individuals are noteworthy since they some share with E. p. schotti DAPI-dark/CMA3-bright bands on the two pairs of small chromosomes and others with E. p. sublineatus without evident DAPI/ CMA3 bands. The distribution and content of constitutive heterochromatin are considered as variable characters for the karyotypes of some reptiles (Olmo et al. 1986). Furthermore, the intraand interspecific variation observed in the C-band patterns would appear to be unrelated to phylogeny
(Odierna et al. 1985). Thus, the diversity observed in the C-banding pattern of the species and subspecies studied here constitutes evidence that supports the evolutionary trend for reptiles.

The number and location of the NORs in a pair of micro-chromosomes is frequent in Serpentes and also in Squamata (Camper and Hanks 1995, Aprea et al. 2006, Mezzasalma et al. 2014). Within Xenodontini, the location in micro-chromosomes has been reported in E. poecilogyrus schotti and three Lygophis species (Trajtengertz et al. 1995, Falcione et al. 2016). In all taxa studied here, a single NOR has been observed in one pair of small chromosomes. 
In most organisms, the repeating unit of the ribosomal genes (rDNA) is often $\mathrm{G}+\mathrm{C}$-rich (Miller 1981, Sumner 2003). The presence of a $\mathrm{CMA}_{3}$-bright band is generally associated to NORs (Sumner 2003, Aprea et al. 2006). From the results of the analysis of fluorescent bandings in $E$. almadensis, the $\mathrm{CMA}_{3}$-bright band placed on one small chromosome pairs could represent an NOR.

The presence of a heteromorphic sex chromosome pair ZZ/ZW has been already previously described in four species of Erythrolamprus: E. miliaris, E. bizona, E. aesculapii venustissimun and E. almadensis (Beçak et al. 1966, 1975, Beçak and Beçak 1969, Gutiérrez et al. 1984). These species share the position of the ZZ/ZW on the $4^{\text {th }}$ chromosome pair of the karyotype, but sex chromosomes $\mathrm{Z}$ and $\mathrm{W}$ shows a variable morphology and size (Beçak et al. 1966, 1975, Beçak and Beçak 1969, Gutiérrez et al. 1984). The ZW heteromorphism is considered a putative synapomorphy of Colubroidea (Oguiura et al. 2009), and their position on the $4^{\text {th }}$ pair is reported in colubrids and crotalids species (Baker et al. 1972, Beçak and Beçak 1969, 1981, Singh 1972, Gutiérrez et al. 1979, Mengden and Stock 1980, Ota 1999, Aprea et al. 2003, 2006, Falcione et al. 2016). However, based on partial gene content, part of the sex chromosomes is homologous in all families of caenophidian snakes (Rovatsos et al. 2015).

In the present study, the $2^{\text {nd }}$ and $6^{\text {th }}$ chromosome pairs are assigned as sex chromosome pair (ZZ/ ZW) in both E. almadensis and E. p. caesius, respectively. In females of E. almadensis, both homologous are metacentric but differ in size. However, in males the two chromosomes are of equal size. Furthermore, the smallest metacentric chromosome of pair 2 exhibits a pericentromeric $\mathrm{C}$-positive band on the $\mathrm{p}$ arm in females. Therefore, the presence of this heteromorphic pair in females allows us to propose that chromosomal pair 2 would be the ZW sex pair, because the smallest metacentric chromosome would be resting to females, being $\mathrm{W}$ chromosome.

In the female diploid chromosome complement of E. poecilogyrus caesius, the pair 6 is heteromorphic by morphology, since one of the chromosomes is metacentric and the other sub-telocentric. In contrast, male karyotype the same pair is homomorphic, both homologues being subtelocentric. Similarly, in females only the subtelocentric chromosome of this pair has a C-positive band in the p-arm, whereas in males C-positive bands are distinguished in the p-arm of both subtelocentric chromosomes. Considering to these result, we suggest that the metacentric chromosome of the pair 6 would be the $\mathrm{W}$ chromosome, whereas the subtelocentric chromosome the $\mathrm{Z}$, because it is only present in the female complement. Pericentric inversions, amplification of pre-existent heterochromatin or the addition of new heterochromatin, and deletions of euchromatic regions would have been the mechanisms involved in the evolution of sex chromosomes of Erythrolamprus almadensis and E. p. caesius as there were proposed in Serpentes (Ohno 1967, Ray-Chaudhuri et al. 1971, Singh et al. 1976, Beçak 1983, Matsubara et al. 2006).

Cytotaxonomy plays a key role in elucidating the taxonomy and chromosomal evolution of snakes when morphological characteristics are insufficient for the resolution of taxonomic problems (Gutiérrez and Bolaños 1981). From this point of view, we provide an overview of the current cytogenetic Erythrolamprus genus. Moreover, our results show that E. p. caesius $(2 \mathrm{n}=28)$ has karyological specific characteristics that differentiate it from E. p. schotti and E. p. sublineatus $(2 \mathrm{n}=32)$. This karyotype might constitute a mechanism of reproductive isolation making it a different species: Erythrolamprus caesius. Complementarily morphological and molecular analysis should provide further information. 


\section{ACKNOWLEDGMENTS}

We thank to Dirección de Recursos Naturales de las provincias de Corrientes y Chaco (Argentina) for providing collecting permits. We thank Rodrigo Cajade, María del Rosario Ingaramo, José Ruiz García, José Luis Acosta, Martín Ortiz, Soledad Palomas, Roberto Aguirre and Victor Zaracho for their invaluable help in the fieldwork and provision specimens. We also thank Diego Baldo for providing specimens of E. ceii, Juan Martin Ferro facility the DNAr probe. This work was supported by the Consejo Nacional de Investigaciones Científicas y Técnicas (CONICET) (Argentina) and the Secretaría General de Ciencia y Técnica, Universidad Nacional del Nordeste (Argentina).

\section{REFERENCES}

APREA G, GENTILLI A, ZUFFI MAL AND ODIERNA G. 2006. The karyology of Vipera aspis, V. atra, V. hugyi, and Cerastes vipera. Amphibia-Reptilia 27: 113-119.

APREA G, ODIERNA G, ANDREONE F, GLAW F AND VENCES M. 2003. Unusual karyotype in the Malagasy colubrid snake Mimophis mahfalensis. Amphibia-Reptilia 24: 215-219.

BAKER RJ, MENGDEN GAAND BULL JJ. 1972. Karyotypic studies of thirty-eight species of North American snakes. Copeia: 257-265.

BEAUPRE SB, JACOBSON ER, LILLYWHITE HB AND ZAMUDIO K. 2004. Guidelines for use of amphibians and reptiles in field and laboratory research, $2^{\text {nd }}$ Edition. Revised by the Herpetological Animal Care and Use Committee (HACC) of the American Society of Ichthyologists and Herpetologists, Lawrence, Kansas, 42 p.

BEÇAK ML, BEÇAK W, CHEN TR AND SHOFFNER RN. 1975. Chromosome Atlas: Fish, Amphibians, Reptiles and Birds. Vol. 3. In: Benirschke K and Hsu TC (Eds), Springer-Verlag. Berl, $248 \mathrm{p}$.

BEÇAK ML, BEÇAK W, ROBERTS RN, SHOFFNER EP AND VOLPE EP. 1966. Chromosome Atlas: Fish, Amphibians, Reptiles, and Birds. Vol 2. In: Benirschke K and Hsu TC (Eds), Springer-Verlag. Berl, 240 p.

BEÇAK W. 1983. Evolution and differentiation of sex chromosomes in lower vertebrates. Differentiation (Suppl) 23: 3-12.

BEÇAK W AND BEÇAK ML. 1969. Cytotaxonomy and chromosomal evolution in Serpentes. Cytogenetics 8: 247262.
BEÇAK W AND BEÇAK ML. 1981. Behaviour of the ZW Sex Bivalent in the Snake Bothrops jararaca. Chromosoma 83: 289-293.

BEÇAK W, CARNEIRO SM AND BEÇAK ML. 1971. Cariologia comparada em seis especies da colubrídeos (serpentes). Cienc Cult, vol. 23, 123 p.

BRESSA MJ, PAPESCHI AG, VÍTKOVÁ M, KUBÍČKOVÁ S, FUKOVÁ I, PIGOZZI MI AND MAREC F. 2009. Sex chromosome evolution in cotton stainers of the genus Dysdercus (Heteroptera: Pyrrhocoridae). Cytogenet Genome Res 125: 292-305.

CAMPER DJ AND HANKS BG. 1995. Variation in the Nucleolus Organizer Region among New World Snakes. J Herpetol 29: 468-471.

CEI JM. 1993. Reptiles del noroeste, nordeste y este de la Argentina. Herpetofauna de las selvas subtropicales, puna y pampas. Mus Reg Di Sci Nat XIV, 949 p.

CURCIO FF, PIACENTINI V AND FERNANDES DS. 2009. On the status of the snake genera Erythrolamprus Boie, Liophis Wagler and Lygophis Fitzinger (Serpentes, Xenodontinae). Zootaxa 2173: 66-68.

DIXON JR AND MARKEZICH AL. 1992. Taxonomy and geographic variation of Liophis poecilogyrus (Wied) from South America (Serpentes: Colubridae). Tex J Sci 44(2): 131-165.

FALCIONE C, HERNANDO A, BARRASO DA AND DI PIETRO D. 2016. Karyotypes of four species of Xenodontini snakes (Squamata: Serpentes) and implication for their taxonomy. Contrib Zool 85(3): 265-273.

FERNANDES DA SILVA D. 2006. Revisão sistemática de Liophis poecilogyrus (Wied-Neuwied, 1825) (Serpentes: Colubridae). Tese de Doutorado. UFRJ/MN/Programa de Pós-Graduação em Ciências Biológicas, 261 p.

GRAZZIOTIN FG, ZAHER H, MURPHY RW, SCROCCHI G, BENAVIDES MA, ZHANG YP AND BONATTO SL. 2012. Molecular phylogeny of the New World Dipsadidae (Serpentes: Colubroidea): a reappraisal. Cladistics 28: 437-459.

GUTIÉRREZ JM AND BOLAÑOS R. 1981. Polimorfismo cromosómico intraespecífico en la serpiente de coral Micrurus nigrocinctus (Ophidia: Elapidae). Rev Biol Trop 29(1): 115-122.

GUTIÉRREZ JM, SOLÓRZANO A AND CERDAS L. 1984. Estudios cariológicos de cinco especies de serpientes costarricenses de la familia Colubridae. Rev Biol Trop 32: 263-267.

GUTIÉRREZ JM, TAYLOR RT AND BOLAÑOS R. 1979. Cariotipos de diez especies de serpientes costarricenses de la familia Viperidae. Rev Biol Trop 27: 309-319.

HOWELL WM AND BLACK DA. 1980. Controlled silverstaining of nucleolus organizer regions with a protective colloidal developer: a 1- step method. Experientia 3: 10141015. 
LEVAN A, FREDGA K AND SANDBERG A. 1964. Nomenclature for centromeric position on chromosomes. Hereditas 52: 201-220.

MATSUBARA K, TARUI H, TORIBA M, YAMADA K, NISHIDA-UMEHARA C, AGATA K AND MATSUDA Y. 2006. Evidence for different origin of sex chromosomes in snakes, birds, and mammals and step-wise differentiation of snake sex chromosomes. P Natl Acad Sci 103: 1819018195.

MENGDEN GA AND STOCK D. 1980. Chromosomal evolution in Serpentes; a comparison of $\mathrm{G}$ and $\mathrm{C}$ chromosome patterns of some colubrid and boid genera. Chromosoma 79: 52-61.

MEZZASALMA M, ANDREONE F, BRANCH WR, GLAW F, GUARINO FM, NAGY ZT, ODIERNA G AND APREA G. 2014. Chromosome evolution in pseudoxyrhophiine snakes from Madagascar: a wide range of karyotypic variability. Biol J Linn Soc 112: 450-460.

MILLER OL. 1981. The nucleolus, chromosomes, and visualization of genetic activity. J Cell Biol 91: 15s-27s.

MORENO R, NAVARRO J, ITURRA P AND VELOZO M. 1987. The karyotype of Philodryas chamissonis (Colubridae). Identification of nucleolar organizer region (NOR) and sex chromosomes by banding methods. Rev Bras Genet X 3: 497-506.

ODIERNA G, OLMO E AND COBROR O. 1985. C-band variability in some Lacertidae (Sauria, Reptilia). Experientia 41: 944-946.

OGUIURA N, FERRAREZZI H AND BATISTIC RF. 2009. Cytogenetics and molecular data in snakes: a phylogenetic approach. Cytogenet Genome Res 127: 128-142.

OHNO S. 1967. Sex chromosomes and sex-linked genes. Springer Verlag, Berlin, $192 \mathrm{p}$.

OLMO E. 2005. Rate of chromosome changes and speciation in reptiles. Genetica 125: 185-203.

OLMO E. 2008. Trends in the evolution of reptilian chromosomes. Oxford Journals 48(4): 486-493.

OLMO E, ODIERNA G AND COBROR O. 1986. C-band variability and phylogeny of Lacertidae. Genetica 71: 6374.

OTA H. 1999. Karyotype of Pareas iwasakii: The first chromosomal description of a Pareatine snake (Colubridae). Japanese Journal of Herpetology 18: 16-18.

PAPESCHI AG. 1988. C-banding and DNA content in three species of Belostoma (Heteroptera) with large differences in chromosome size and number. Genetica 76: 43-51.

PECCININI-SEALE D. 1981. New developments in vertebrate cytotaxonomy. IV. Cytogenetic studies in reptiles. Genetica 56: $123-148$

POGGIO MG, BRESSA MJ AND PAPESCHI AG. 2011. Male meiosis, heterochromatin characterization and chromosomal location of rDNA in Microtomus lunifer
(Berg, 1900) (Hemiptera: Reduviidae: Hammacerinae). Comp Cytogenet 5: 1-22.

PYRON RA, BURBRINK FT AND WIENS JJ. 2013. A phylogeny and revised classification of Squamata, including 4161 species of lizards and snakes. BMC Evolutionary Biology, vol. 13, 93 p.

RAY-CHAUDHURI SP, SINGH L AND SHARMA T. 1971. Evolution of sex chromosomes and formation of $\mathrm{W}$ chromatin in snakes. Chromosoma 33: 239-251.

REEVES A AND TEAR J. 2000. MicroMeasure for Windows, version 3.3. Available at: http://www.colostate.edu/Depts/ Biology/MicroMeasure.

ROVATSOS M, VUKIC' J, LYMBERAKIS P AND KRATOCHVI'L L. 2015. Evolutionary stability of sex chromosomes in snakes. Proc R Soc B 282: 20151992.

SINGH L. 1972. Evolution of karyotypes in snakes. Chromosoma 38: 185-236.

SINGH L AND MAJUMDAR KC. 1994. Behaviour of microchromosome-associated satellite DNA in the banded krait, Bungarus fasciatus (Ophidia, Elapidae). J Genet 73(1): 1-15.

SINGH L, PURDOM IF AND JONES KW. 1976. Satellite DNA and evolution of sex chromosomes. Chromosoma 59: 43-62.

SUMNER AT. 2003. Chromosomes: organization and function, $1^{\text {st }}$ ed., Blackwell Science Ltd., Malden, USA.

TRAJTENGERTZ I, BEÇAK ML AND RUIZ IR. 1995. Ribosomal cistrons in Bothrops neuwiedi (Serpentes) subspecies from Brazil. Genome 38: 601-606.

TRAUT W. 1976. Pachytene mapping in the female silkworm Bombyx mori L. (Lepidoptera). Chromosoma 58: 275-284.

UETZ P AND HOŠEK J. 2013. The Reptile Database. Available at: http://www.reptile-database.org/. Accessed on April 1, 2015.

UNO Y ET AL. 2012. Inference of the Protokaryotypes of Amniotes and Tetrapods and the Evolutionary Processes of Microchromosomes from Comparative Gene Mapping. PLoS ONE 7(12): 1-12.

VIDAL N, DEWYNTER MI AND GOWER DJ. 2010. Dissecting the major American snake radiation: A molecular phylogeny of the Dipsadidae Bonaparte (Serpentes, Caenophidia). Comptes Rendus Biologies 333: 48-55.

VIDAL N, KINDL SG, WONG A AND HEDGES SB. 2000. Phylogenetic relationships of Xenodontine snakes inferred from $12 \mathrm{~s}$ and $16 \mathrm{~s}$ ribosomal RNA sequences. Mol Phylogenet Evol 14: 389-402.

WHITE MJD. 1968. Models of speciation. Science 159: 10651070.

WHITE MJD. 1969. Chromosomal rearrangements and speciation in animal. Annu Rev Genet 3: 75-98.

ZAHER H, GRAZZIOTIN FG, CADLE JE, MURPHY RW, MOURA-LEITE JC AND BONATTO SL. 2009. 
Molecular phylogeny of advanced snakes (Serpentes, Caenophidia) with an emphasis on South American Xenodontines: a revised classification and descriptions of new taxa. Pap Avulsos Zool 49: 115-153.

\section{APPENDIX}

Species names, sex, collection numbers and localities of specimens of Erythrolamprus sampled in this study. UNNEC $=$ Colección Herpetológica de la Universidad Nacional del Nordeste, Corrientes, Argentina.

Erythrolamprus ceii $(\mathrm{n}=3)$ : UNNEC- 12690 (ふ), UNNEC- 12691 (す) and UNNEC- 12692 (す), Isla de Cañas $\left(22^{\circ} 53^{\prime} 55^{\prime \prime} \mathrm{S}, 64^{\circ} 39^{\prime} 59^{\prime \prime} \mathrm{W}\right)$, Salta province, Argentina.

Erythrolamprus almadensis $(\mathrm{n}=8)$ : UNNEC-10621 (ठ) Isla Apipé $\left(27^{\circ} 34^{\prime} 20^{\prime \prime} \mathrm{S}\right.$, $\left.56^{\circ} 48^{\prime} 05^{\prime \prime} \mathrm{W}\right)$, Corrientes province, Argentina;

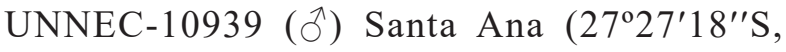
$\left.58^{\circ} 39^{\prime} 12^{\prime \prime} \mathrm{W}\right)$, Corrientes province, Argentina; UNNEC-11093 (), UNNEC-11243 (ð), UNNEC-11826 (q) and UNNEC-11827 (ð) San

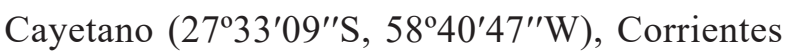
province, Argentina; UNNEC-11012 (q) Chavarria

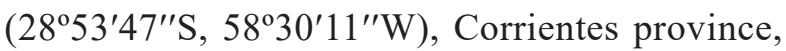
Argentina; UNNEC-11048 (ठ઼) Concepción $\left(28^{\circ} 17^{\prime} 24^{\prime \prime} \mathrm{S}, 58^{\circ} 02^{\prime} 08^{\prime \prime} \mathrm{W}\right)$, Corrientes province, Argentina.

Erythrolamprus poecilogyrus caesius (n = 11): UNNEC-11092 (q), UNNEC-10897 (q), UNNEC-11898 (ㅇ) and UNNEC-11107 (ㅇ) Taco Pozo ( $\left.25^{\circ} 37^{\prime} 02^{\prime \prime} \mathrm{S}, 63^{\circ} 16^{\prime} 07^{\prime \prime} \mathrm{W}\right)$, Chaco province, Argentina; UNNEC-12751 () and UNNEC-12750

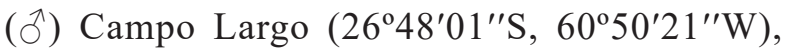
Chaco province, Argentina; UNNEC-12693 (ぶ) Pampa Del Índio $\left(26^{\circ} 01^{\prime} 07^{\prime \prime} \mathrm{S}, 59^{\circ} 58^{\prime} 01^{\prime \prime} \mathrm{W}\right)$, Chaco province, Argentina; UNNEC-11094 (ठ) San Roque $\left(28^{\circ} 34^{\prime} 28^{\prime \prime} \mathrm{S}, 58^{\circ} 42^{\prime} 32^{\prime \prime} \mathrm{W}\right)$, Corrientes province, Argentina; UNNEC-11828 (), UNNEC-11829 () and UNNEC-11830 (ぷ) Calchaqui $\left(30^{\circ} 01^{\prime} 06^{\prime \prime} \mathrm{S}, 60^{\circ} 19^{\prime} 36^{\prime \prime} \mathrm{W}\right)$, Santa Fé province, Argentina.
Erythrolamprus poecilogyrus schotti $(\mathrm{n}=19)$ : UNNEC-9930 (ふ) and UNNEC-9934 (†) Galarza $\left(28^{\circ} 04^{\prime} 20^{\prime \prime} \mathrm{S}, 56^{\circ} 38^{\prime} 44^{\prime \prime} \mathrm{W}\right)$, Corrientes province, Argentina; UNNEC-10073 () Loreto $\left(27^{\circ} 45^{\prime} 21^{\prime \prime} \mathrm{S}\right.$, $\left.57^{\circ} 18^{\prime} 42^{\prime \prime} \mathrm{W}\right)$, Corrientes province, Argentina;

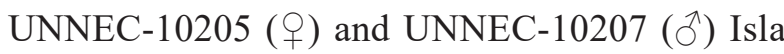
Apipé $\left(27^{\circ} 31^{\prime} 12^{\prime \prime} \mathrm{S}, 56^{\circ} 44^{\prime} 32^{\prime \prime} \mathrm{W}\right)$, Corrientes province, Argentina; UNNEC-12696 ( $\lesssim)$ and UNNEC-12697 (q) Tres Cerros (29 06'47"S, $\left.56^{\circ} 55^{\prime} 08^{\prime \prime} \mathrm{W}\right)$, Corrientes province, Argentina;

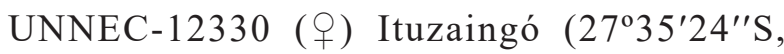
$56^{\circ} 41^{\prime} 22^{\prime \prime} \mathrm{W}$ ), Corrientes province, Argentina;

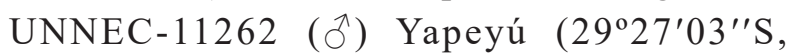
$\left.56^{\circ} 49^{\prime} 06^{\prime \prime} \mathrm{W}\right)$, Corrientes province, Argentina; UNNEC-11095 (ぶ) and UNNEC-12699 (ㅇ)

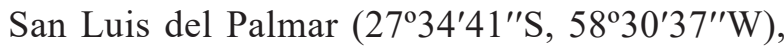
Corrientes province, Argentina; UNNEC-11245 (ðへ)

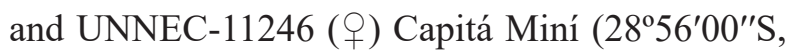
$\left.58^{\circ} 22^{\prime} 10^{\prime \prime} \mathrm{W}\right)$, Corrientes province, Argentina; UNNEC-11247 (ㅇ) San Cayetano (27 33'09"S, $\left.58^{\circ} 40^{\prime} 47^{\prime \prime} \mathrm{W}\right)$, Corrientes province, Argentina; UNNEC-12752 (q) Santa Ana (272 $27^{\prime} 18^{\prime \prime}$, $\left.58^{\circ} 39^{\prime} 12^{\prime \prime} \mathrm{W}\right)$, Corrientes province, Argentina;

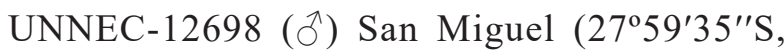
$\left.57^{\circ} 35^{\prime} 19^{\prime \prime} \mathrm{W}\right)$, Corrientes province, Argentina; UNNEC-12700 (q) and UNNEC-12701 (ठึ) Empedrado $\left(27^{\circ} 47^{\prime} 52^{\prime \prime} \mathrm{S}, 58^{\circ} 45^{\prime} 40^{\prime \prime} \mathrm{W}\right)$, Corrientes province, Argentina; UNNEC-11249 (ㅇ) Capital $\left(27^{\circ} 28^{\prime} 16^{\prime \prime} \mathrm{S}, 58^{\circ} 50^{\prime} 22^{\prime \prime} \mathrm{W}\right)$, Corrientes province, Argentina.

Erythrolamprus poecilogyrus sublineatus $(\mathrm{n}=$ 9): UNNEC-10626, 10630 ( $\left.{ }^{\top}\right)$ and UNNEC-10572, 10628 (q) Concepción ( $\left.28^{\circ} 25^{\prime} 44^{\prime \prime} \mathrm{S}, 5^{\circ} 57^{\prime} 54^{\prime \prime} \mathrm{W}\right)$, Corrientes province, Argentina; UNNEC-12703 (ठ) and UNNEC-12702 (q) Tres Cerros $\left(29^{\circ} 06^{\prime} 47^{\prime \prime} \mathrm{S}, 56^{\circ} 55^{\prime} 08^{\prime \prime} \mathrm{W}\right)$, Corrientes province, Argentina; UNNEC-9823 (ざ) Galarza (28 $05^{\circ} 48^{\prime \prime}$, $\left.56^{\circ} 41^{\prime} 07^{\prime \prime} \mathrm{W}\right)$, Corrientes province, Argentina;

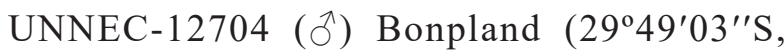
$\left.57^{\circ} 25^{\prime} 41^{\prime \prime} \mathrm{W}\right)$, Corrientes province, Argentina; UNNEC-10940 (ふ) Guardamonte (32 05'19"S, $\left.59^{\circ} 15^{\prime} 39^{\prime \prime} \mathrm{W}\right)$, Entre Rios province, Argentina. 


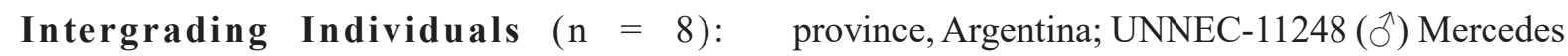
UNNEC-10583 (ठّ) and UNNEC-10572 10629 (28 $\left.55^{\prime} 24^{\prime \prime} \mathrm{S}, 58^{\circ} 17^{\prime} 50^{\prime \prime} \mathrm{W}\right)$, Corrientes province, (q) Concepción $\left(27^{\circ} 55^{\prime} 01^{\prime \prime} \mathrm{S}, 57^{\circ} 27^{\prime} 29^{\prime \prime} \mathrm{W}\right)$, Argentina; UNNEC-11246 (q) Capitá Miní Corrientes province, Argentina; UNNEC-11481 (ㅇ) Monte Caseros ( $\left.30^{\circ} 27^{\prime} 47^{\prime \prime} \mathrm{S}, 58^{\circ} 01^{\prime} 20^{\prime \prime} \mathrm{W}\right)$, Corrientes province, Argentina; UNNEC-11480

(ठ) Sauce $\left(30^{\circ} 10^{\prime} 08^{\prime \prime} \mathrm{S}, 59^{\circ} 01^{\prime} 55^{\prime \prime} \mathrm{W}\right)$, Corrientes ( $\left.28^{\circ} 56^{\prime} 00^{\prime \prime} \mathrm{S}, 58^{\circ} 22^{\prime} 10^{\prime \prime} \mathrm{W}\right)$, Corrientes province, Argentina; UNNEC-12755 (さ) and UNNEC-2753 (ㅇ) Santa Ana $\left(27^{\circ} 27^{\prime} 18^{\prime \prime} \mathrm{S}, 58^{\circ} 39^{\prime} 12^{\prime \prime} \mathrm{W}\right)$, Corrientes province, Argentina. 